\title{
ERATO 岩田ヒト膜受容体構造プロジェクト中間評価報告書
}

【研究総括】岩田 想 (京都大学大学院医学研究科／教授、インペリアルカレッジロンドン 分子生命科学科／教授）

【評価委員】(あいうえお順)

諏訪 牧子（産業技術総合研究所生命情報工学研究センター／主幹研究員）

箱嶋 敏雄 (奈良先端科学技術大学院大学情報科学研究科／教授）

村上 聡 (東京工業大学大学院生命理工学研究科/教授)

山本 雅貴 （理化学研究所播磨研究所放射光科学総合研究センター基盤研究 部／部長)

\section{評価の概要}

ERATO 岩田ヒト膜受容体構造プロジェクトは、G タンパク質共役型受容体 (GPCR) をモデル として、大量発現、結晶化、X線回折データ測定におけるボトルネックを平行して解消しながら、 困難であると言われてきた膜タンパク質の三次元構造決定の技術を確立することを目的としてい る。ヒト GPCR の系統的な構造解析は、ポストゲノム時代の構造生物研究の中でもとりわけ期待 されている重要かつ挑戦的な研究課題であり、達成されたときのインパクトは極めて大きい。

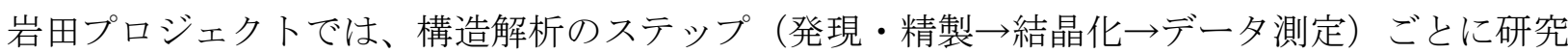
グループを構成しており、それぞれにおいて成果が生まれている。例えば、酵母による高速な高 発現スクリーニング技術を確立したこと、新手法によって期待するモノクローナル抗体を得る技 術を確立したこと、さらに自動結晶化技術と膜タンパク質結晶のスクリーニング、データ測定の ためのシステムを立ち上げたことなどは評価できる。これらの成果は若手研究者を積極的に登用 した結果生まれたものであり、次世代を担う研究者の育成という意味でも本プロジェクトは貢献 している。

グループ間の連携という意味ではやや不足があり、折角の優れた技術がまだ十分には生かされ ていない。今後は、残り短い 2 年間であることを認識しながら早急に構造決定すべきターゲット を絞り、研究資源を集中するならば、目的の達成が十分に期待できるところまで来ている。

これらを総合的に判断すれば、岩田プロジェクトの研究水準は優秀なものであると言える。今 後はグループ間で連携して互いに創出した技術を活用し合うことで、プロジェクト終了までに GPCRの構造決定を是非とも達成してもらいたい。 


\section{1. 研究プロジェクトの設定および運営}

\section{$1-1$. プロジェクトの全体構想}

タンパク質の構造解析の技術は 90 年代から急速な発展を遂げて、タンパク質構造データバン クには現在 5 万以上の構造データが登録されている。ところが、そのほとんどは可溶性タンパク 質のものであり、膜タンパク質の構造解析はあまり進んでいない。その要因として（1）発現、 大量精製が困難（2）水溶性でないため結晶化が困難（3）そのため良好な X 線回折データが得 られないことが挙げられる。一方、現在市販されている医薬の 5 割以上が、細胞膜中に存在する 膜タンパク質、特に G タンパク質共役型受容体 (GPCR) をターゲットにしており、GPCRの構 造の理解は合理的創薬に不可欠である。

本プロジェクトでは、ヒトゲノム配列解析の成果を活用して、膜タンパク質の大量発現・精製 技術、膜タンパク質の可溶化・結晶化技術、新世代放射光技術等、各種技術を組み合わせること により、創薬に要求されるヒトGPCRの構造決定を系統的に行う技術の確立を目指す。

具体的には、（1）ヒトGPCR の CDNAを迅速に各種ベクターに組み込み、これをタンパク質 の機能を保持したまま発現可能な酵母を用いて大量発現するとともに、結晶化の妨げとなる糖鎖 の除去方法の開発等を行い、ヒト GPCR の大量産生・精製技術を確立する。（2）膜タンパク質 は、可溶化するために用いる界面活性剤のミセルに覆われて結晶化が困難であるが、親水性を増 大する別のタンパク質を結合することによって結晶性を向上することが可能なことから、ヒト GPCR に適した結合タンパク質を作成する技術を開発する。（3）GPCR と結合タンパク質を含 む溶液と結晶化を促進する沈殿剂をナノリットル・オーダーで滴下・混合する等の独自技術と、 結晶化したプレートをX 線回折計に直接マウントして、結晶化最適条件を高速スクリーニングす る機械制御システムを確立する。（4）最終的な解析には、回折の弱い結晶からも高精度のデータ を得られるビームラインと、新たな結晶マウンティングシステムを組み合わせることで、放射線 損傷を防ぎながら高分解能データが得られる超低ノイズのデータ計測系を構築する。

これら一連の技術の確立により、医薬の主要なターゲットの一つであるヒト GPCR の構造を効 率的に決定することが可能になり、その知見に基づいた副作用を抑えた医薬の開発や、テーラー メイド医療の実現はもとより、細胞生物学や分子生物学等の学問領域においても、GPCR を介し た情報伝達に関する研究の進展に寄与すると考えられる。このように, 本研究の成果は、戦略目 標「遺伝子情報に基づくたんぱく質解析を通した技術革新」に資するものと期待される。

\section{$1-2$. プロジェクトの枠組みや研究体制、および研究活動の状況}

上記の構想を実現するために、岩田研究総括は「受容体産生」「結晶創成」「結晶化・X 線測定 システム開発」の3グループを設置した。受容体産生、結晶創成グループは日本の高度なタンパ ク質生産技術を有した研究施設に付随した形で設置するとともに、結晶化・X 線測定システム開 発グループはイギリスの新しいシンクロトロン（ダイアモンド）に設置した。2008 年 1 月には 結晶化リガンド構築グループを結晶創成グループから独立させており、研究の進渉に応じて体制 を柔軟に組み替える工夫が見られる。

本プロジェクトでは異分野の若手研究者が各グループにわたって十分に活躍しており、同時に 育成されている。この点では総括がリーダーシップを良好に発揮している。その一方で、新しい アッセイや精製手法等の情報が十分に各グループに行き渡っておらず、互いの研究が並列、独立 に進んでいる部分が見受けられるために、グループ間での連携という観点では改善を要する。ま た、5 年間の時限プロジェクト研究を担う上で、幾つもの実験の中からすべき実験を取捨選択し て推進するときの方針が徹底しきれていない感がある。本プロジェクトの場合、研究実施場所の 
移転や二カ国での実施という難しさがあったのは事実であるが、残すところ約 2 年となった今、 総括の強力な意志決定のもと、これまで以上に研究員が一丸となって目標達成に向けて邁進す心゙ き状況にあることを指摘しておきたい。

具体的な成果については次節で詳細を述べるとするが、各グループで良好な成果を挙げている ものと評価する。目指している要素技術はかなり成熟してきており、GPCR 構造決定の土台は整 いつつある。今後はグループ間で連携して互いに創出した技術を活用し合うことで、プロジェク 卜終了までに GPCR の構造決定を是非とも達成してもらいたい。

〔研究プロジェクトの設定および運営〕 b (やや不的確・非効果的な部分がある（若干の工 夫を要する))

〔研究活動の状況〕 a（良好な研究活動・展開を示しており今後にも期待できる）

\section{2. 研究成果}

\section{2-1. 受容体産生グループ}

受容体産生グループは、G タンパク質共役型受容体（GPCR）の大量生産に向けて大量発現、 ならびに活性を保持した精製法の確立という、二つの課題に精力的に取り組んでいる。プロジェ クトとして創薬に重要なターゲットとなる GPCR の CDNAを 100 クローン以上も選択して、そ の寸べてについて大量発現の可能性についてスクリーニングを進めた。その結果 20-30 クローン において高発現系を実現している点はプロジェクトの中間段階での成果として評価できる。

プロジェクト前半では酵母による生産を柱とした GPCR の大量生産に取り組んできており、

Pichia pastoris 系と Saccaromyces cerevisiae 系で発現システムを構築して、酵母による高速な 高発現スクリーニング技術を確立した点は高く評価したい。

複数の酵母による高発現株スクリーニング系および大量生産システムによる精製サンプルから は、残念ながら構造決定に至っていないが、今後の構造解析研究において利用可能な要素技術も 確立されており、膜タンパク質の大量生産に向けた新しい技術として評価できる。また、その技 術開発の過程で熱安定性の重要性についての知見を得るとともに、そこで開発した熱安定性の評 価方法およびその評価指針は本プロジェクトの重要な成果である。

現在、2007 年、2008 年に 3 件報告された ClassA GPCR（アドレナリン受容体、アデノシン 受容体)の構造解析で使用されていた昆虫細胞系での大量生産システムの立ち上げを進めている。 酵母を用いた研究から、GPCR 構造解析の成否はその熱安定性が鍵となるであろうという指針を 得ているので、熱安定性向上が期待される昆虫細胞系は大変重要である。発現系の検討の中でも、 この系への注力は必要であろう。

今後は、酵母による高発現株スクリーニング系の知見を活用して、昆虫細胞系に組み合わせて GPCR 大量生産システムを確立することが本プロジェクト成功の鍵となるであろう。現在までの研 究成果を生かして、得られた GPCR リストをもとにターゲットを厳選したうえで、研究資源を集 中して GPCR 大量生産システムを確立して、残された時間の中で構造解析に結びつけていただき たい。

\section{2-2．結晶創成グループ}

本グループは、ヒト GPCR に対してその結晶性を向上させるモノクローナル抗体を作成するた めの普遍的な技術体系を確立することを目指している。これまでに有力な手法がいくつも生み出 されており、実際にそれらの手法で期待する抗体を得て迅速にスクリーニングできていることは 
評価に值する。一般的な抗体工学の発展に資する手法として特筆すべきものである。

上記以外にも、Fab フラグメントとヒト GPCR との共精製や共結晶化、新規 Native-PAGE 法 など、様々な技術開発とシステム化を進めており、その技術開発の水準はいずれも高いところに あると判断する。

目的の GPCR サンプルが決まれば、ここに挙げた幾つもの洗練された要素技術を展開すること により、有効な抗体の作成、スクリーニングができるだろう。今後は受容体産生グループを中心 に他グループとの連携をさらに深めて、早期の GPCR サンプルの大量調製・結晶化プロセスの確 立を目指して欲しい。

\section{2-3. 結晶化リガンド構築グループ}

結晶化リガンド構築グループは、ハイスループットの結晶化リガンド作成を目標に 2008 年 1 月に発足した新しいグループである。ハイブリドーマ法ではなく、免疫したマウスにより得られ た抗体遺伝子の cDNA ライブラリーから目的の抗体を、ファージディスプレイ法を用いて選択し て、発現・精製することを可能にした。抗体作成の迅速化に有効な技術と考えられるので、これ を確立したことを高く評価したい。

系は動いているが、ネイティブ構造を認識する抗体がとれなかったことは残念である。結晶創 成グループの開発したスクリーニング方法で、立体構造認識能を有する抗体を得る方法を用いる べきであろう。グループとしては立ち上げ途上であろうが、他グループ (特に結晶創成グループ) との守備範囲の違いと、連携を深めるべきところを明確にした上で、研究・作業内容の重複を無 くした効率的な運営を期待したい。

また、このグループの技術による膜タンパク質高親和性抗体は、結晶化リガンドとしてだけで はなく、医学薬学方面での応用が期待できるものであり、プロジェクトの初期目標から少し離れ るが、波及効果のある成果と言えよう。

\section{$2-4$. 結晶化・X 線測定システム開発グループ}

結晶化・X 線測定システム開発グループは、英国ダイアモンド放射光施設のマイクロフォーカ スビームラインの計画遅延にも関わらず、短期間のうちに Membrane Protein Laboratory (MPL) を立ち上げて、現在までに様々な結晶化システムを導入してロボットによるハイスループット結 晶化および観察システムを構築した。ヒト膜タンパク質結晶の構造解析にむけた技術開発および その準備の進渉状況は概ね順調であると言えよう。ヒト由来トランスポーターなどの複数例の構 造解析を成功させている。

GPCR の構造解析を掲げた本プロジェクトにおいては、テストサンプルとしての扱いになるが、 本グループが成功させたトランスポーターの立体構造解析は、生物学的知見の獲得と膜タンパク 質結晶化の汎用的技術確立の両面から高く評価できる成果である。

今後は GPCR 構造決定に向けて完成度を高めて、京都から受け入れる GPCR サンプルの結晶 化・構造解析を延滞なく実行することが期待される。

以上、各グループの成果に対する所見を述べてきた。各グループで目的を達成するための優れ た要素技術は開発されてきているが、それらを本格的に活用するまでには至っていない。結晶化 すべきターゲットが絞り切れていないことも要因の一つであろう。残された 2 年では GPCR にフ オーカスを絞り、少なくとも 1 個〜数個の構造決定に注力する必要がある。

これは創出した優れた要素技術を選択、集中して、結晶構造解析に至るまでのフローが描けれ ば、十分可能になると期待している。フローを描く際には、本プロジェクトを取り巻く状況が、 
2007、2008 年に海外で立て続けに GPCR の構造が決定されたことで急速に変化していることを 強く意識する必要がある。独創性を維持しつつも、遅れをとらないように柔軟に計画を変更して 行く視点も必要であろう。

GPCR の構造決定によって、開発された要素技術の有効性が高く評価されることを期待したい。 これらを総合的に判断して、現時点の成果としては良好であり、今後にも期待できると判断し た。

[研究成果の現状と今後の見込]

a（成果として良好であり、今後にも期待できる）

\section{3. 総合所見}

ヒト GPCR をモデルとして、大量発現、結晶化、X線回折データ測定におけるボトルネックを 平行して解消しながら三次元構造の決定技術を確立することを目的とする本プロジェクトは、難 易度が高く、挑戦的・独創的であり ERATO に相応しいものである。本プロジェクトが生み出し た成果によって目的とする GPCR の構造決定が可能となれば、学術的価值はもちろん、産業・経 済的価值も極めて大きく、波及効果は大きいと考えられる。

個々の研究グループの成果を見ると、若手のグループリーダーを擁して優れた技術が生まれて おり、目標達成に必要な要素技術は整いつつある。プロジェクト開始当初に比べ、関連分野の情 勢が急速かつ大きく変化したことを視野に入れながら、グループ間の情報共有を進めて、有望な サンプルを早急に絞り込み、抗体の応用や結晶化のフローに載せるように、鋭意奮闘してもらい たい。具体的な GPCR の構造決定の成果は今後の展開に持ち越されたが、これまでに得られた要 素技術を十二分に活用して到達できる水準に来ており、総合的には優秀な研究水準にあると判断 した。

〔総合評価〕Ａ（優秀な研究水準にある）

以上 